\title{
PELATIHAN BUDIDAYA SISTEM VERTIKULTUR PADA PETANI BAWANG MERAH DI DESA BULUHARJO KABUPATEN MAGETAN
}

\author{
Pujiati, Dwi Rosita Sari, Cicilia Novi Primiani, Mohammad Arfi Setiawan \\ Universitas PGRI Madiun \\ pujiati@unipma.ac.id,primiani@unipma.ac.id,marfis@unipma.ac.id
}

\begin{abstract}
Buluharjo Village, Magetan Regency is a rural area, the majority of which are horticultural crops. Shallots are one of the commodities in the region. The productivity of shallots for the last three years has decreased due to the reduction in agricultural land caused by the construction of housing projects. The decline in shallot production is caused by the lack of land and the presence of plant pests such as worms, caterpillars, fungi and bacteria. The use of high chemical fertilizers, improper selection of seeds makes the quantity and quality of shallot production not optimal. The purpose of the activity is to provide training on red onion cultivation with verticulture techniques as a solution for using narrow land. The method used is pre survey, survey, socialization and training. The activity was carried out for 6 months. The result of the activity is an increase in understanding of modern agricultural techniques, namely verticulture in the field of red onion farming. Public understanding of modern agricultural systems, and increasing the productivity of shallots. The community is very enthusiastic and actively involved in applying vertical culture techniques. The community can apply the shallot verticulture technique on narrow land.
\end{abstract}

Keywords: cultivation, red onions, training, vertical farming

\section{ANALISIS SITUASI}

Bawang merah merupakan salah satu tanaman holtikultura sebagai komoditas rempah-rempah yang sering digunakan masyarakat sebagai bumbu dapur dan sebagai obat (Lubis, 2019; Asrianto dkk., 2019). Komoditas bawang merah di Indonesia dapat memenuhi permitaan pasar baik dalam dan luar negeri, permintaan bawang merah meningkat setiap tahunnya (Lay $d k k$., 2018; Taufiq $d k k .$, 2021). Berbagai daerah di Indonesia telah banyak mengembangkan budidaya bawang merah, sehingga terpenuhinya komoditas bawang merah (Hadi \& Maharani, 2018; Seran, \& Taena, 2019; Astoro, 2021). Pengembangan budidaya bawang merah banyak dilakukan di wilayah dataran rendah dan dataran tinggi. Salah satu daerah pengembangan budidaya bawang merah adalah di Kabupaten Magetan, Jawa Timur, yaitu Desa Buluharjo.

Desa Buluharjo merupakan salah satu desa yang memiliki letak yang cukup strategis, secara geografis. Sebelah barat Desa Buluharjo berbatasan langsung dengan
Kelurahan Plaosan yang merupakan kota Kecamatan Plaosan. Ditinjau dari aspek ekonomi Desa Buluharjo merupakan desa yang sangat potensial karena letaknya dekat pusat kecamatan, demikian juga kondisi lahan pertanian yang relatif datar dan subur sangat mendukung produktifitas hasil pertanian.

Mayoritas mata pencaharian masyarakat Desa Buluharjo sebagai petani dan sebagian kecil bekerja sebagai wiraswasta dan pegawai negeri sipil. Pertanian di desa Buluharjo didominasi oleh pertanian pangan yaitu: padi, jagung, sayuran, bawang merah dengan sistem pengairan irigasi dari telaga Sarangan Kabupaten Magetan. Bawang merah merupakan salah satu komoditas sayuran unggulan yang sudah lama telah diusahakan oleh petani secara intensif. Bawang merah merupakan komoditas Desa Buluharjo yang selalu ditanam oleh masyarakat desa setiap tahunnya.

Produktivitas bawang merah Desa Buluharjo selama tiga tahun terakhir mengalami penurunan akibat permasalahan 
yang dihadapi masyarakat akibat berkurangnya lahan pertanian yang disebabkan pembangunan proyek perumahan di Kecamatan Plaosan Kabupaten Magetan. Penurunan produksi bawang merah disebabkan oleh minimnya lahan dan adanya serangan hama tanaman (cacing, ulat, jamur). Modal pembelian bibit dan pupuk kimia yang mahal, ketergantungan para petani pada bibit bawang impor serta minimnya pengetahuan petani akan teknik budidaya bawang merah ramah lingkungan juga merupakan permasalahan penurunan produktivitas bawang merah di Desa Buluharjo.

Penyusutan lahan pertanian di daerah Plaosan Kabupaten Magetan akibat pembangunan beberapa kompleks perumahan. Mengingat bahwa lokasi daerah yang strategis yaitu dekat dengan telaga Sarangan dan iklim yang sejuk membuat para developer tertarik untuk membangun kompleks perumahan. Sampai pada awal tahun 2016 ini terdapat 3 proyek pembangunan perumahan di kecamatan Plaosan. Satu perumahan sudah launching, 1 sedang peroses pembangunan dan 1 perumahan sedang dalam wacana.

Berdasarkan hasil survey dan wawancara pada petani bawang merah, harga bawang merah yang terus meningkat sejak awal tahun 2015 membuat para petani enggan menanam bawang merah karena modal yang dibutuhkan untuk pembelian umbi bibit sangat besar. Sampai awal tahun 2017 harga bawang merah terus naik hingga 40.000/kg dalam kondisi basah. Bawang merah kering untuk yang biasa dipakai untuk bibit umbi 50.000/kg. Sehingga dapat diestimasikan untuk 1 hektar lahan diperlukan kurang lebih 1,5ton bawang merah belum untuk biaya perawatan dan pupuk.

Fluktuasi produksi bawang merah selalu terjadi pada usaha tani bawang merah yang disebabkan adanya perbedaan produksi pada musim kemarau dan musim penghujan musim penghujan petani bawang merah di Desa Buluharjo cenderung kurang termotivasi untuk menanam bawang merah karena intensitas serangan hama pada musim ini sangat tinggi terutama ulat grayak dan jamur sangat tinggi sehingga tingkat kegagalannya pun sangat besar.

Solusi yang ditawarkan untuk mengalami permasalahan produktivitas mawang merang adalah teknik budidaya bawang merah dengan sistem vertikultur pada pipa PVC. Menurut Wartapa $d k k$., (2010) dan Fathurrahman (2020), teknik vertikultur merupakan cara bercocok tanam dengan susunan vertikal atau ke atas menuju udara bebas. Untuk media vertikultur biasanya disusun secara vertikal juga. Penempatan media tanam vertikultur bawang merah menggunakan paralon yang dapat digunakan sebagai alternatif tempat media tanam. Cara bercocok tanam dengan teknik vertikultur sangat cocok diterapkan pada lahan yang sempit terutama di pekarangan rumah yang tidak memiliki lahan terlalu luas. Penerapan sistem pertanian vertikultur diharapkan dapat menambah produksi para petani terkait terkendalanya proses alih fungsi lahan.

Tujuan kegiatan adalah meningkatkan produktivitas bawang merah di Desa Buluharjo melalui kegiatan sosialisasi/penyuluhan dan pelatihan kepada petani bawang merah di Desa Buluharjo untuk mencapai target yang diharapkan. Target yang diharapkan dalam kegiatan ini adalah memberikan solusi permasalahan yang dihadapi petani bawang merah di Desa Buluharjo yang meliputi 1) petani bawang merah mampu membuat system vertikultur menggunakan pipa PVC, 2) keterpahaman petani bawang merah dalam mengaplikasikan teknik vertikultur, 3) petani bawang merah mampu menanam bawang merah dengan system vertikultur.

\section{METODE PELAKSANAAN}

Pelaksanaan program kegiatan ini dilakukan selama 8 bulan pada kelompok tani bawang merah Desa Buluharjo Kecamatan Plaosan, Kabupaten Magetan. 
Pendekatan yang dilakukan kepada masyarakat melalui penggalian informasi secara formal dan informal, diskusi, sosialisasi/penyuluhan, pelatihan dan pendampingan. Semua metode pendekatan tersebut tertuang dalam tahapan-tahapan pelaksanaan program ini yang meliputi:

\section{Pra survey}

Pada tahap ini dilakukan diskusi informal secara individu dan kelompok dengan petani bawang merah di Desa Buluharjo Kecamatan Plaosan Kabupaten Magetan. Penggalian informasi tentang sistem produksi bawang merah, pengetahuan, dan permasalahan yang dihadapi petani dalam berusaha tani bawang merah. Hasil diskusi yang diperoleh pada tahap ini digunakan sebagai dasar penyusunan kuesioner untuk formal survey.

2. Survey formal

Tahap formal survey dilakukan wawancara individual dengan responden menggunakan kuesioner terstruktur. Pertanyaan yang diajukan kepada responden mengenai (1) karakteristik responden, (2) alasan petani melakukan usahatani bawang merah, (3) persepsi petani tentang minimnya lahan untuk usahatani bawang merah (4) jumlah dan harga input output. Permasalahan yang ditanyakan atau dikonfirmasi kepada petani adalah permasalahan yang relevan dengan kondisi petani setempat seperti yang dimunculkan petani sendiri pada tahapan prasurvey yaitu permasalahan yang berhubungan dengan: penyempitan lahan untuk usahatani bawang merah (2) jenis organisme pengganggu tanaman (OPT) yang menyerang tanaman, (3) kesuburan tanah (4) kualitas benih, (5) kelangkaan input, (6) kelangkaan permodalan, pascapanen, (8) pemasaran hasil, dan (9) peringkat permasalahan yang ada.
3. Sosialisasi/penyuluhan

Program sosialisasi/penyuluhan dilakukan untuk meningkatkan wawasan dan pemahaman masyarakat tentang teknik budidaya/usahatani bawang merah pada lahan sempit yaitu secara vertikultur, kelebihan vertikultur, alat dan bahan yang dibutuhkan dalam vertikultur, perawatan vertikultur dan analisis biaya dalam teknik budidaya ini.

4. Pelatihan pembuatan teknik vertikultur dan penanaman sampai pemanenen bawang merah

Program pelatihan diberikan setelah penyuluhan berakhir. Pelatihan vertikultur bawang merah ini dilakukan di greenhouse sederhana dengan ukuran $3 \times 10$ di lahan yang dikelola desa. Petani bawang diberikan pelatihan pembuatan system vertikultur dengan pipa PVC. Kegiatan dilanjutkan dengan teknik penanaman sampai pemanenan bawang merah

\section{HASIL DAN PEMBAHASAN}

Hasil pelaksanaan kegiatan pada program ini dapat didiskripsikan sesuai dengan metode pelaksanaan yang diterapkan. Pelaksanaan program pertama pada saat pra survey melalui observasi dan wawancara kepada para petani bawang merah di Desa Buluharjo Kecamatan Plaosan Kabupaten Magetan. Petani bawang merah di Desa Buluharjo tergabung dalam kelompok tani, dengan anggota sejumlah 70 orang. Berdasakan hasil observasi di lahan pertanian dan wawancara para petani bawang merah, menunjukkan bahwa pengetahuan masyarakat terhadap budidaya bawang merah masih bersifat konvensional. Masyarakat belum mengenal dan memahami sistem pertanian modern yang dapat dijadikan solusi dari berbagai masalah-masalah pertanian yang sering dihadapi seperti serangan hama maupun penyakit, mahalnya perawatan, pengaruh musim dan sebagainya. 
Pelaksanaan kegiatan kedua adalah survey formal, dengan memberikan kuisioner kepada para petani bawang. Adapun indikator dalam kuisioner yang diberikan kepada para petani bawang merah meliputi (1) alasan petani melakukan usahatani bawang merah, (2) persepsi petani tentang minimnya lahan untuk usahatani bawang merah (4) jumlah dan harga input output. Adpun hasil pelaksanaan survey adalah, petani bawang merah kekurangan lahan pertanian penanaman bawang merah karena sempitnya lahan pertanian. Kesuburan tanah pertanian semakin menurun, karena seringnya penggunaan pestisida. Banyaknya hama penyakit tanaman bawang merah, yang dapat menurunkan produkstivitas bawang merah. Kondisi ini memerlukan pembenahan manajemen dalam pengelelolaan pertanian bawang merah.

Pelaksanaan

kegiatan

sosialisasi/penyuluhan mengenai teknik budidaya/usahatani bawang merah pada lahan sempit yaitu secara vertikultur. Pelaksanaan kegiatan sosialisasi/penyuluhan dilakukan dengan membuat greenhouse dan memasang blok pipa. Petani bawang merah sangat antusias dalam mengikuti kegiatan sosialisasi. Adapun tahap pelaksanaan sosialisasi/penyuluhan dengan peserta para petani bawang merah. Berdasarkan hasil kegiatan mengenai keterpahaman teknik budidaya bawang merah dengan teknik vertikultur, $96 \%$ petani bawang telah memahami tenik vertikultur dan $90 \%$ petani bawang merah mau mencoba teknik vertikultur dalam budidaya bawang merah.

Teknik pelaksanaan kegiatan yang keempat adalah pelatihan pembuatan greenhouse dengan system vertikultur. Adapun prosedur pembuatannya vertikultur bawang merah adalah sebagai berikut:

a. Membuat blok alas berdiameter $60 \mathrm{~cm}$ untuk mencetak blok tempat polivinilklorida (PVC) ditegakkan.

b. Menyiapkan Pipa berdiameter 4 inci sepanjang $2 \mathrm{~m}$ sebagai wadah tanaman. c. Membuat 96 lubang tanam berdiameter $4 \mathrm{~cm}$ dengan bor listrik bermata bulat, jarak antar titik $15 \mathrm{~cm}$.

d. Memasang pipa yang telah dilubangi di blok dengan posisi tegak, selnjutnya mengisi dengan media tanam dengan campuran sekam mentah, serbuk gergaji, kompos dan tenah dengan perbandingan $0,25: 0,25: 1: 1$.

e. Memasukkan pipa nutrisi berdiameter 1 inci yg telah diberi lubang ke dalam pipa PVC berisi media tanam. Fungsinya supaya nutrisi yang dituangkan sampai ke dasar pipa. Bagian bawah pipa nutrisi disumbat dengan karet sandal jepit. Tujuannya agar tanah tidak masuk ke dalam pipa nutrisi.

f. Menanam bibit dengan memasukkan sebagian umbi bawang merah kedalam lubang di dinding pipa agar umbi tertanam kuat, topang dengan lidi. Kegiatan pelaksanaan kegiatan terdapat pada Gambar 1.

Proses vertikultur bawang merah di mulai dengan pembuatan blog tempat PVC berdiri, dilanjutkan pembuatan lubang pada PVC dengan mata bor berukuran $4 \mathrm{~cm}$, pengisian medium dengan komposisi sekam, serbuk gergaji, pupuk kandang, dan tanah. Media yang ditanam memiliki kelembaban kurang lebih $60 \%$. Media dipadatkan agar tidak menyusut sewaktu perawatan penyiraman. Dalam perawatan barang merah sama dengan perawatan pertanian bawang merah sistem lahan dengan memberikan pupuk daun dan pupuk untuk umbi. 

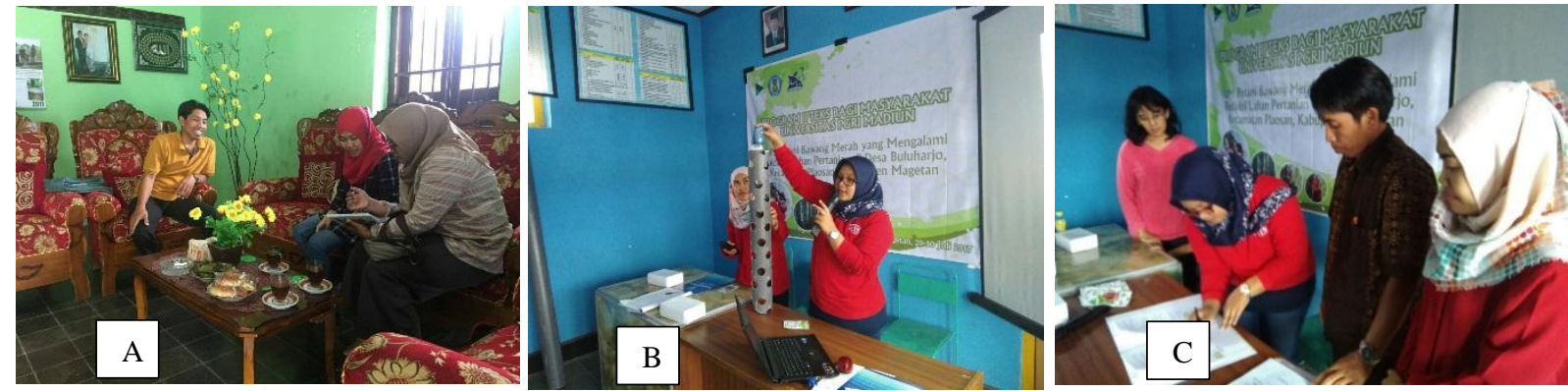

Gambar 1. Proses survey dan konsolidasi dengan warga dan petani bawang merah setempat (A); pelatihan kepada masyarakat dan kelompok tani (B); penandatangan berita acara serah terima produk teknologi

Proses pengairan dapat dilakukan dengan dua cara yaitu melalui lubang atas paralon dengan bantuan botol minum yang diposisikan terbalik dan yang sudah dilubangi dengan tujuan agar air dapat meresap ke bawah. Metode pengairan lain yaitu dengan sistem semprot/spray. Sistem semprot ini efektif dilakukan dalam proses pemberian pupuk. Pemupukan di mulai dengan melarutkan pupuk dalam air sesuai takaran kemudian di semprotkan ke tanaman, metode ini sangat praktis untuk aplikasi pada sistem vertikultur. Vertikultur merupakan sistem budidaya tanaman dengan sistem tegak/vertikal sehingga sistem ini lazim disebut sebagai vertikultur. Kelebihan utama dari sistem vertikultur adalah menghemat lahan, oleh karena itu sistem ini sangat cocok diaplikasikan untuk optimalisasi produksi pertanian pada lahan sempit.

Proses pelaksanaan kegiatan memberikan dampak signifikan terhadap sistem pertanian di Desa Buluharjo, Kecamatan Plaosan, Kabupaten Magetan. Teknik vertikultur dalam budidaya bawang merah merupakan solusi bagi petani bawang merah di Desa Buluharjo. Kondisi ini adanya ancaman alih fungsi lahan menjadi kompleks perumahan sehingga masyarakat perlu dibekali hardskill dan softskill terkait perkembangan pertanian modern. Masyarakat sangat antusias mengikuti kegiatan pelatihan teknik vertikultur, hal ini terbukti dengan banyaknya warga yang mengaplikasikan sistem vertikultur ini untuk dibudidaya di pekarangan rumah. Masyarakat masih memulai mengaplikasikannya di pekarangan rumah masing-masing dan mencoba 1-5 paralon yang ditanami bawang merah untuk kebutuhan sehari-hari.

Budidaya tanaman dengan vertikultur dapat dilakukan di pekarangan rumah dengan skala ruang sempit karena disusun secara vertikal (Yulida, 2012; Damanik, \& Suryanto, 2018). Sistem pertanian vertikultur lebih hemat biaya operasional karena pupuk yang diberikan tidak mudah tercuci sehingga pemberian total dosis lebih sedikit jika dibandingan dengan sistem tanam konvensional di lahan terbuka. Jumlah gulma yang tumbuh lebih sedikit, efisiensi dalam penggunaan lahan budidaya karena dapat diterapkan di lahan yang sempit namun cukup intensitas cahaya serta dapat digunakan sebagai keindahan untuk pekarangan rumah karena memiliki nilai estetika yang lebih jika penanaman yang dilakukan dikombinasikan dan disusun rapi dengan tanaman lain (Sutarminingsih, 2008). Adapun hasil teknik vertikultur bawang merah di Desa Buluharjo Kecamatan Palosan Kabupaten Magetan seperti pada Gambar 2. 

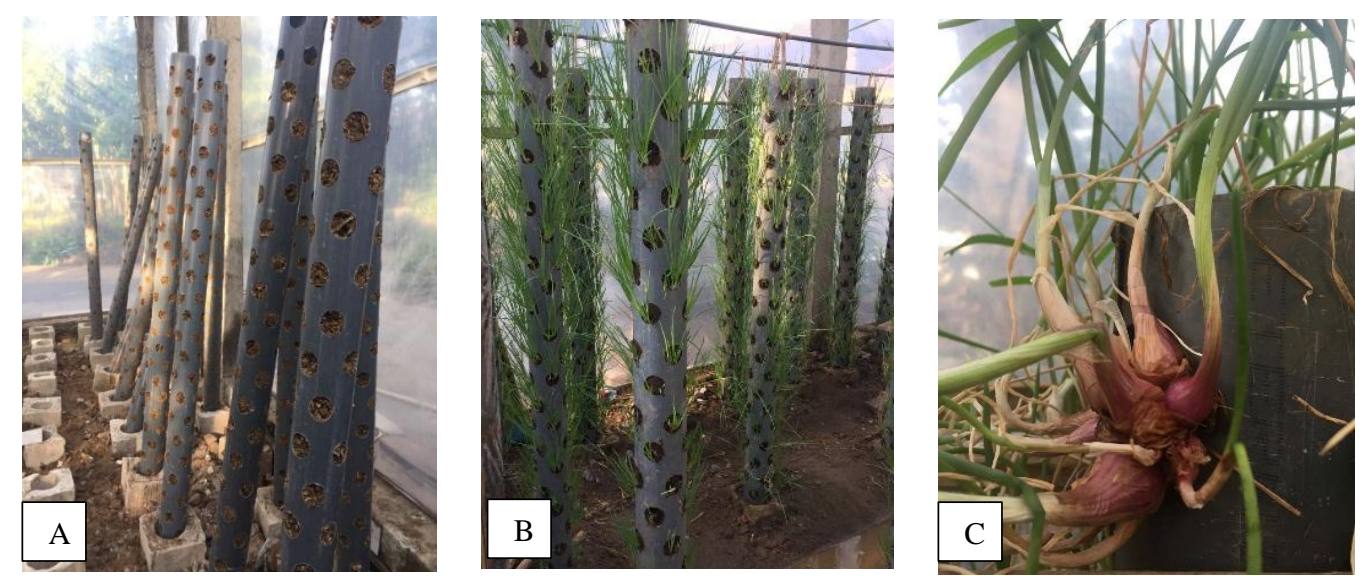

Gambar 2. Penampakan peletakan paralon (A), penampakan pertumbukan bawang merah (B), penampakan tumbuhnya bawang merah (C)
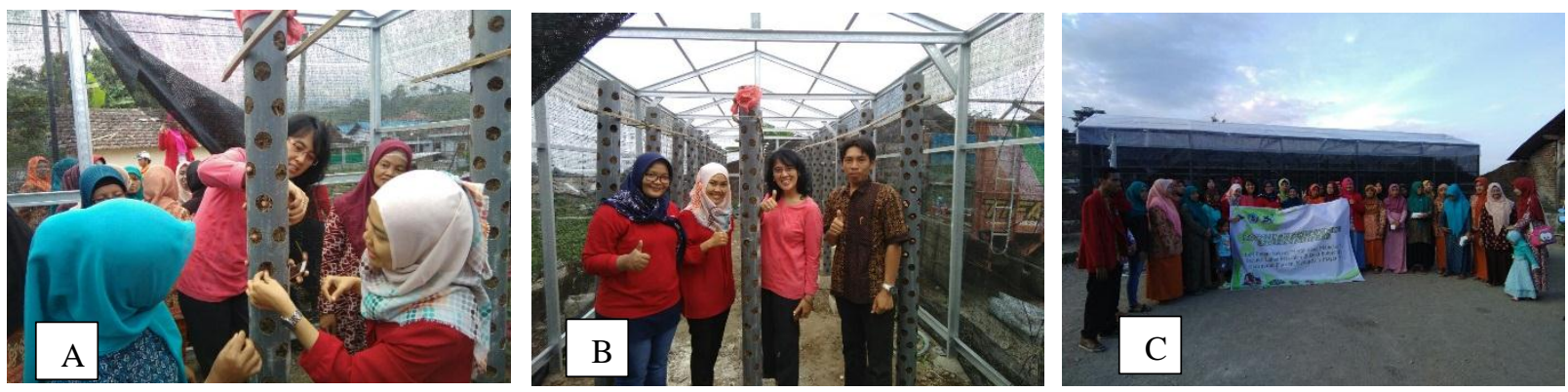

Gambar 3. (A) penanaman secara simbolis oleh kepala; (B) hasil penanaman benih bawang merah bersama warga (C) foto bersama masyrakat dan kelompok tani

Hasil yang diperoleh dari pelaksanaan kegiatan pelatiahn kepada petani bawang merah antara lain adalah: (1) meningkatnya pemahaman masyarakat tentang pertanian pada lahan sempit, (2) meningkatkan keterampilan masyarakat tentang sistem pertanian modern (vertikultur), (3) meningkatkan pemahaman masyarakat terhadap sistem pemupukan, (4) peningkatan pemahaman teknologi terutama dalam bidang pertanian, (5) peningkatan omzet produksi pertanian melalui pemanfataan teknologi pertanian terbaru yang minim biaya produksi, (6) realisasi swasembada bawang merah di Indonesia, (7) peningkatan kesejahteraan masyarakat di Desa Buluharjo akan tercapai. Adapun pelaksanaan kegiatan seperti terdapat pada Gambar 3.

Pelaksanaan kegiatan pelatihan budidaya bawang merah dengan teknik vertikultur juga dilakukan proses monitoring dan evaluasi. Monitoring dilakukan untuk mengetahui, mendata, dan memberikan solusi untuk permasalahan permasalahan yang dihadapi. Pelaksanaan monitoring dilakukan setelah aplikasi program selama 3 kali yaitu seminggu setelah paska panen, sebulan paska panen, dan seminggu sebelum panen.

Kegiatan monitoring terhadap pelaksanaan program digunakan untuk menentukan keberlanjutan program yang akan ditentukan. Evaluasi dan keberlanjutan program dilakukan dengan metode wawancara secara formal dan informal kepada petani baik secara individu maupun kelompok. Evaluasi program dilakukan untuk mengetahui keberhasilan program sosialisasi dan pelatihan. Para petani bawang merah yang sudah diberikan penyuluhan dan pelatihan tentang budidaya bawang merah pada lahan sempit akan memberi pelatihan kepada kelompok tani lain, karang taruna, maupun ibu-ibu PKK sebagai upaya pemberdayaan lahan sempit di area lahan 
pertanian Desa Buluharjo Kecamatan Plaosan Kabupaten Magetan.

\section{KESIMPULAN}

Vertikultur merupakan sistem budidaya tanaman dengan sistem tegak/vertikal sehingga sistem ini biasa disebut sebagai vertikultur. Kelebihan utama dari sistem ini adalah hemat lahan, oleh karena itu sistem ini sangat cocok diaplikasikan untuk optimalisasi produksi pertanian pada lahan sempit. Hasil dari pelaksanaan kegiatan adalah meningkatnya pemahaman masyarakat petani bawang merah dengan sistem/teknik pertanian modern pada lahan sempit. Masyarakat khususnya petani bawang merah sangat antusias dan mau melakukan budidaya bawang merah di lahan pertanian masingmasing. Meningkatnya produktivitas bawang merah Desa Buluharjo Kecamatan Plaosan Kabupaten Magetan.

\section{DAFTAR PUSTAKA}

Asrianto, A., Siswadi, B., \& Mahfudz, M. (2019). Faktor-Faktor Yang Mempengaruhi Produksi Pada Usahatani Bawang Merah Di Desa Banjarejo Kecamatan Ngantang Kabupaten Malang. Jurnal Sosial Ekonomi Pertanian dan Agribisnis, 7(1).

Astoro, A. (2021). Kajian Teknis Pengembangan Budidaya Bawang Merah (Allium Ascalonicum L.) Di Kecamatan Belitang III Kabupaten OKU Timur. Jurnal Bakti Agribisnis, 7(01), 44-51.

Damanik, S. A., \& Suryanto, A. (2018). Efektivitas penggunaan mikoriza dan PGPR (plant growth promoting rhizobacteria) terhadap tanaman bawang merah (Allium ascalonicum L.) pada pipa PVC sistem vertikultur. Jurnal Produksi Tanaman, 6(4).

Fathurrahman, F. (2020). Kajian komposisi media tumbuh dan pupuk sampah kota terhadap produktivitas bawang merah dengan teknik vertikultur. VIABEL: Jurnal Ilmiah Ilmu-Ilmu Pertanian, 14(1), 54-62.

Hadi, S., \& Maharani, E. (2018). Strategi pengembangan bawang merah di kota pekanbaru. DINAMIKA PERTANIAN, 34(3), 219-228

Lay, S. M. C., Kapa, M. M., \& Nainiti, S. P. (2018). Analisis permintaan komoditi bawang merah di Kabupaten Timor Tengah Selatan. Buletin Ilmiah IMPAS, 19(3), 32-39.

Lubis, Z. (2019). Strategi pengembangan komoditi bawang merah di kabupaten simalungun. Prosiding Seminar Nasional Hasil Penelitian. 2(2), 16851691.

Seran, A., \& Taena, W. (2019). Tingkat Penerapan Teknologi Pertanian dan Strategi Pengembangan Budidaya Bawang Merah (Allium cepa. L) di Desa Tes Kecamatan Bikomi Utara Kabupaten Timor Tengah Utara. AGRIMOR, 4(3), 29-33.

Sutarminingsih, L. (2008). Pola Bertanam Secara Vertikal Vertikultur. Yogyakarta: Kanisius.

Taufiq, M., Rahmanta, R., \& Ayu, S. F. (2021). Permintaan Dan Penawaran Bawang Merah Di Provinsi Sumatra Utara. JURNAL AGRICA, 14(1).

Wartapa A., S. Sugihartiningsih, S. Astuti, dan Sukadi. (2010). Pengaruh Jenis Pupuk dan Tanaman Antagonis Terhadap Hasil Cabai Rawit (Capsicum frutencens) Budidaya Vertikultur. IlmuIlmu Pertanian, 6(2), 152-156.

Yulida, R. (2012). Kontribusi usahatani lahan pekarangan terhadap ekonomi rumah tangga petani di Kecamatan Kerinci Kabupaten Pelalawan. J. Indonesian Journal of Agricultural Economics. 3 (20), 135-154 